\title{
The spectrum between antiphospholipid syndrome and systemic lupus erythematosus
}

\author{
Nancy Agmon-Levin • Yehuda Shoenfeld
}

Published online: 17 January 2014

(C) Clinical Rheumatology 2014

Systemic lupus erythematosus (SLE) and the antiphospholipid syndrome (APS) are interconnected autoimmune diseases. APS was primarily described by Graham Hughes in a group of patients with SLE who suffered from obstetric morbidity and/or recurrent thromboses [1]. Along the years, it was noted that patients may exhibit APS manifestations with no characteristic of SLE classified as primary APS, whereas APS presenting concomitantly with SLE was termed secondary APS. Unlike SLE, APS was not considered to be a systemic disease. However, in the course of time, APS was found to be associated with damage to various organs and systems and to evolve into SLE in about $10 \%$ of patients. Moreover, the expression lupus-like APS was coined to define APS patients displaying systemic "SLE features" although SLE criteria cannot be fulfilled [2, 3].

For years, clinicians and scientist have tried to better discriminate between these conditions. Certain manifestations of SLE such as the presence of antinuclear antibodies, complement activation, or immune mediated kidney disease were accepted as markers to distinguish this disease from primary APS. However, in the last decades, the presence of antinuclear antibodies, hypocomplementemia, non-thrombotic kidney disease, and renal failure were all documented in patients diagnosed with primary APS and the activation of complement was found to be related with APS in experimental models [2]. Last but not the least, the antiphospholipid antibodies serve as criteria for both syndromes and are present in $100 \%$ of APS patients and in up to $40 \%$ of SLE patients, of which many will eventually develop overt APS [2-4]. Hence,

N. Agmon-Levin · Y. Shoenfeld $(\bowtie)$

Zabludowicz Center for Autoimmune Diseases, Sheba Medical

Center, Tel Hashomer 52621, Israel

e-mail: shoenfel@post.tau.ac.il

N. Agmon-Levin • Y. Shoenfeld

Sackler Faculty of Medicine, Tel-Aviv University, Tel Aviv, Israel the great heterogeneity and overlap between these autoimmune diseases raised the debate: Are they a single condition with varied phenotypes, or different diseases with diverse pathogenic mechanisms sharing phenotypes? [5-7].

In the current issue, Freire PV et al. [8] retrospectively analyzed a cohort of 80 patients with primary APS of which $14(17.5 \%)$ progressed within $5.2 \pm 4$ years to SLE-APS. The latter was significantly younger at diagnosis and their disease duration was longer. In addition, the presence of autoantibodies and particularly antinuclear ones were noted in $100 \%$ of patients finally diagnosed with concomitant APSSLE compared to $51 \%$ of patients that remained with the diagnosis of primary APS $(P=0.0005)$. Moreover, specific autoantibodies (i.e., anti-dsDNA, anti-ribosomal $\mathrm{P}$, anti-Ro/ SS-A, anti-La/SS-B, and anti-U1RNP) were exclusively found among patients ultimately diagnosed with concomitant SLE, supporting the notion that primary APS may differ from APS associated with SLE.

The role of autoantibodies as markers and players in the mosaic of autoimmunity is well established [9, 10]. For instance, antinuclear antibodies alongside a wide array of related specific autoantibodies are key markers and servers as criteria for diagnoses of some autoimmune diseases [9]. Furthermore, several specific antibodies were linked with clinical manifestations of different diseases further supporting their plausible pathogenic role $[11,12]$. But perhaps the most substantial evidence is a series of studies demonstrating that specific autoantibodies can be detected years before the development of an overt disease. Indeed, Arbuckle et al. [13] found that $88 \%$ of SLE patients were antibody positive up to 30 years prior to diagnosis and a stepwise accumulation of these antibodies was a marker of the preclinical stage of SLE. Similarly, the presence of anti-mitochondrial antibodies (AMA) in primary biliary cirrhosis (PBC), anti-Saccharomyces cerevisiae antibodies in Chron's disease, and anti-neutrophil cytoplasmic antibodies (ANCA) both in ulcerative colitis and in ANCA- 
associated vasculitis were documented years before diseases were overt [14-16]. Noteworthy, antiphospholipid antibodies presence may precede the diagnosis of APS in patients diagnosed both with primary or secondary APS.

Autoimmune diseases are chronic conditions initiated by the loss of tolerance to self-antigens, followed by a preclinical stage, usually marked by autoantibodies production. The appearance of full blown disease, namely the clinical stage, is strongly linked with the individual genetic susceptibility and exposure to diverse environmental factors $[17,18]$. Notably, the presence of specific autoantibodies may predict the disease phenotype and the production of these autoantibodies is also determined by genetics and the environment [19]. Both human leukocyte antigen (HLA) and non-HLA genes are linked with autoantibodies production, suggesting that the genetic predisposition to the development of a specific autoantibody clues to a precise clinical portrait [17]. Regarding SLE and APS, distinct polymorphisms of common genetic factors have been associated with both conditions suggesting that these entities are variants within a continuum of disease [2].

The role of environmental factors in induction of autoantibodies production and disease phenotypes has been extensively studies, and it seems that a wide array of such factors contribute to autoimmunity. Numerous infectious agents have been related to autoimmunity and production of autoantibodies [20-22] as well as with evident diseases such as SLE and APS [23-27]. Additional factors such as hormones [28, 29], vitamins such as vitamin D [30-32], sun exposure, etc. were also allied the pathogenesis of both SLE and APS [33].

Reflecting on the question, are APS and SLE distinct diseases or not? It seems that the truth is halfway. Thus, the notion that these autoimmune conditions represent a spectrum ranging from primary APS through concomitant diseases to isolated SLE had been accepted by many auto-immunologists and is supported by clinical, genetic, and environmental studies [2]. In this issue, the study of Freire PV et al. [8] supported, on the one hand, the concept of a continuum between primary APS and concomitant SLE-APS. On the other hand, Freire PV et al. [8] were able to identify predictive factors of progression along this spectrum, namely early age of onset and the presence of specific autoantibodies as markers of a change from primary APS to APS-SLE. This stands in agreement with the perception that in the near future, we may be able to predict the risk of an individual to develop autoimmunity or to evolve from one autoimmune disease to another [34, 35]. The ability to analyze and define genetic factors has made genetic analysis common and in certain cases part of routine evolution. Current determination of serological markers (i.e., autoantibodies, vitamin levels, hormone levels, etc.) has changed dramatically in recent years as the usage of automated multivariant platforms became feasible, and the era of immune array and chips which enable detections of tens and hundreds of these markers is at our door [36].
Disclosures None.

\section{References}

1. Hughes GR (1985) The anticardiolipin syndrome. Clin Exp Rheumatol 3(4):285-286

2. Shoenfeld Y, Meroni PL, Toubi E (2009) Antiphospholipid syndrome and systemic lupus erythematosus: are they separate entities or just clinical presentations on the same scale? Curr Opin Rheumatol 21(5):495-500. doi:10.1097/BOR.0b013e32832effdd

3. Tarr T, Lakos G, Bhattoa HP, Szegedi G, Shoenfeld Y, Kiss E (2007) Primary antiphospholipid syndrome as the forerunner of systemic lupus erythematosus. Lupus 16(5):324-328. doi:10.1177/ 0961203307077993

4. Giannakopoulos B, Krilis SA (2013) The pathogenesis of the antiphospholipid syndrome. N Engl J Med 368(11):1033-1044. doi:10.1056/NEJMra1112830

5. Cervera R, Piette JC, Font J, Khamashta MA, Shoenfeld Y, Camps MT, Jacobsen S, Lakos G, Tincani A, Kontopoulou-Griva I, Galeazzi M, Meroni PL, Derksen RH, de Groot PG, Gromnica-Ihle E, Baleva M, Mosca M, Bombardieri S, Houssiau F, Gris JC, Quere I, Hachulla E, Vasconcelos C, Roch B, Fernandez-Nebro A, Boffa MC, Hughes GR, Ingelmo M, Euro-Phospholipid Project G (2002) Antiphospholipid syndrome: clinical and immunologic manifestations and patterns of disease expression in a cohort of 1,000 patients. Arthritis Rheum 46(4):1019-1027

6. Tincani A, Andreoli L, Chighizola C, Meroni PL (2009) The interplay between the antiphospholipid syndrome and systemic lupus erythematosus. Autoimmunity 42(4):257-259

7. Agmon-Levin N, Mosca M, Petri M, Shoenfeld Y (2012) Systemic lupus erythematosus one disease or many? Autoimmun Rev 11(8): 593-595. doi:10.1016/j.autrev.2011.10.020

8. Freire PV, Watanabe E, dos Santos NR, Bueno C, Bonfá E, de Carvalho JF (2014) Distinct antibody profile: a clue to primary antiphospholipid syndrome evolving into systemic lupus erythematosus? Clin Rheumatol. doi:10.1007/s10067-013-2472-3

9. Agmon-Levin N, Damoiseaux J, Kallenberg C, Sack U, Witte T, Herold M, Bossuyt X, Musset L, Cervera R, Plaza-Lopez A, Dias C, Sousa MJ, Radice A, Eriksson C, Hultgren O, Viander M, Khamashta M, Regenass S, Andrade LE, Wiik A, Tincani A, Ronnelid J, Bloch DB, Fritzler MJ, Chan EK, Garcia-De La Torre I, Konstantinov KN, Lahita R, Wilson M, Vainio O, Fabien N, Sinico RA, Meroni P, Shoenfeld Y (2014) International recommendations for the assessment of autoantibodies to cellular antigens referred to as anti-nuclear antibodies. Ann Rheum Dis 73(1):17-23. doi:10.1136/ annrheumdis-2013-203863

10. Zafrir Y, Gilburd B, Carrasco MG, Kivity S, Sanchez-Castanon M, Lopez-Hoyos M, Mandel M, Szmyrka M, Shoenfeld Y, AgmonLevin N (2013) Evaluation of an automated chemiluminescent immunoassay kit for antinuclear antibodies in autoimmune diseases. Immunol Res 56(2-3):451-456. doi:10.1007/s12026-013-8416-9

11. Sherer Y, Gorstein A, Fritzler MJ, Shoenfeld Y (2004) Autoantibody explosion in systemic lupus erythematosus: more than 100 different antibodies found in SLE patients. Semin Arthritis Rheum 34(2):501537

12. Shoenfeld Y, Twig G, Katz U, Sherer Y (2008) Autoantibody explosion in antiphospholipid syndrome. J Autoimmun 30(1-2):74-83. doi:10.1016/j.jaut.2007.11.011

13. Arbuckle MR, McClain MT, Rubertone MV, Scofield RH, Dennis GJ, James JA, Harley JB (2003) Development of autoantibodies before the clinical onset of systemic lupus erythematosus. N Engl J Med 349(16):1526-1533. doi:10.1056/NEJMoa021933 
14. Agmon-Levin N, Shapira Y, Selmi C, Barzilai O, Ram M, SzyperKravitz M, Sella S, Katz BS, Youinou P, Renaudineau Y, Larida B, Invernizzi P, Gershwin ME, Shoenfeld Y (2010) A comprehensive evaluation of serum autoantibodies in primary biliary cirrhosis. $\mathrm{J}$ Autoimmun 34(1):55-58. doi:10.1016/j.jaut.2009.08.009

15. Israeli E, Grotto I, Gilburd B, Balicer RD, Goldin E, Wiik A, Shoenfeld Y (2005) Anti-Saccharomyces cerevisiae and antineutrophil cytoplasmic antibodies as predictors of inflammatory bowel disease. Gut 54(9):1232-1236. doi:10.1136/gut.2004.060228

16. Radice A, Bianchi L, Sinico RA (2013) Anti-neutrophil cytoplasmic autoantibodies: methodological aspects and clinical significance in systemic vasculitis. Autoimmun Rev 12(4):487-495. doi:10.1016/j. autrev.2012.08.008

17. Perricone C, Agmon-Levin N, Ceccarelli F, Valesini G, Anaya JM, Shoenfeld Y (2013) Genetics and autoantibodies. Immunol Res 56(2-3):206-219. doi:10.1007/s12026-013-8396-9

18. Anaya JM, Kim-Howard X, Prahalad S, Chernavsky A, Canas C, Rojas-Villarraga A, Bohnsack J, Jonsson R, Bolstad AI, Brun JG, Cobb B, Moser KL, James JA, Harley JB, Nath SK (2012) Evaluation of genetic association between an ITGAM nonsynonymous SNP (rs1143679) and multiple autoimmune diseases. Autoimmun Rev 11(4):276-280. doi:10.1016/j.autrev.2011.07.007

19. Reveille JD (2006) The genetic basis of autoantibody production. Autoimmun Rev 5(6):389-398. doi:10.1016/j.autrev.2005.10.012

20. Shapira Y, Poratkatz BS, Gilburd B, Barzilai O, Ram M, Blank M, Lindeberg S, Frostegard J, Anaya JM, Bizzaro N, Jara LJ, Damoiseaux J, Shoenfeld Y, Levin NA (2012) Geographical differences in autoantibodies and anti-infectious agents antibodies among healthy adults. Clin Rev Allergy Immunol 42(2):154-163. doi:10. 1007/s12016-010-8241-Z

21. Agmon-Levin N, Blank M, Paz Z, Shoenfeld Y (2009) Molecular mimicry in systemic lupus erythematosus. Lupus 18(13):1181-1185. doi:10.1177/0961203309346653

22. Almohmeed YH, Avenell A, Aucott L, Vickers MA (2013) Systematic review and meta-analysis of the sero-epidemiological association between Epstein Barr virus and multiple sclerosis. PloS One 8(4):e61110. doi:10.1371/journal.pone.0061110

23. Kivity S, Agmon-Levin N, Blank M, Shoenfeld Y (2009) Infections and autoimmunity-friends or foes? Trends Immunol 30(8):409-414. doi:10.1016/j.it.2009.05.005

24. Cruz-Tapias P, Blank M, Anaya JM, Shoenfeld Y (2012) Infections and vaccines in the etiology of antiphospholipid syndrome. Curr Opin Rheumatol 24(4):389-393. doi:10.1097/BOR. 0b013e32835448b8

25. Berkun Y, Zandman-Goddard G, Barzilai O, Boaz M, Sherer Y, Larida B, Blank M, Anaya JM, Shoenfeld Y (2009) Infectious antibodies in systemic lupus erythematosus patients. Lupus 18(13): 1129-1135. doi:10.1177/0961203309345729

26. Sciascia S, Ceberio L, Garcia-Fernandez C, Roccatello D, Karim Y, Cuadrado MJ (2012) Systemic lupus erythematosus and infections: clinical importance of conventional and upcoming biomarkers. Autoimmun Rev 12(2):157-163. doi:10.1016/j.autrev.2012.03.009

27. Bogdanos DP, Smyk DS, Invernizzi P, Rigopoulou EI, Blank M, Pouria S, Shoenfeld Y (2013) Infectome: a platform to trace infectious triggers of autoimmunity. Autoimmun Rev 12(7):726-740. doi: 10.1016/j.autrev.2012.12.005

28. Shelly S, Boaz M, Orbach H (2012) Prolactin and autoimmunity. Autoimmun Rev 11(6-7):A465-A470. doi:10.1016/j.autrev.2011. 11.009

29. Agmon-Levin N, Rosario C, Katz BS, Zandman-Goddard G, Meroni P, Cervera R, Stojanovich L, Blank M, Pierangeli S, Praprotnik S, Meis E, Seguro LP, Ruffatti A, Pengo V, Tincani A, Doria A, Shoenfeld Y (2013) Ferritin in the antiphospholipid syndrome and its catastrophic variant (cAPS). Lupus 22(13):1327-1335. doi:10. $1177 / 0961203313504633$

30. Agmon-Levin N, Theodor E, Segal RM, Shoenfeld Y (2013) Vitamin $\mathrm{D}$ in systemic and organ-specific autoimmune diseases. Clin Rev Allergy Immunol 45(2):256-266. doi:10.1007/s12016-012-8342-y

31. Agmon-Levin N, Blank M, Zandman-Goddard G, Orbach H, Meroni PL, Tincani A, Doria A, Cervera R, Miesbach W, Stojanovich L, Barak V, Porat-Katz BS, Amital H, Shoenfeld Y (2011) Vitamin D: an instrumental factor in the anti-phospholipid syndrome by inhibition of tissue factor expression. Ann Rheum Dis 70(1):145-150. doi: 10.1136/ard.2010.134817

32. Amital H, Szekanecz Z, Szucs G, Danko K, Nagy E, Csepany T, Kiss E, Rovensky J, Tuchynova A, Kozakova D, Doria A, Corocher N, Agmon-Levin N, Barak V, Orbach H, Zandman-Goddard G, Shoenfeld Y (2010) Serum concentrations of 25-OH vitamin D in patients with systemic lupus erythematosus (SLE) are inversely related to disease activity: is it time to routinely supplement patients with SLE with vitamin D? Ann Rheum Dis 69(6):1155-1157. doi:10. 1136/ard.2009.120329

33. Perricone C, Agmon-Levin N, Shoenfeld Y (2013) Novel pebbles in the mosaic of autoimmunity. BMC Med 11:101. doi:10.1186/17417015-11-101

34. Shoenfeld Y, Blank M, Abu-Shakra M, Amital H, Barzilai O, Berkun Y, Bizzaro N, Gilburd B, Zandman-Goddard G, Katz U, Krause I, Langevitz P, Mackay IR, Orbach H, Ram M, Sherer Y, Toubi E, Gershwin ME (2008) The mosaic of autoimmunity: prediction, autoantibodies, and therapy in autoimmune diseases-2008. Isr Med Assoc J 10(1):13-19

35. Shepshelovich D, Shoenfeld Y (2006) Prediction and prevention of autoimmune diseases: additional aspects of the mosaic of autoimmunity. Lupus 15(3):183-190

36. Fattal I, Shental N, Mevorach D, Anaya JM, Livneh A, Langevitz P, Zandman-Goddard G, Pauzner R, Lerner M, Blank M, Hincapie ME, Gafter U, Naparstek Y, Shoenfeld Y, Domany E, Cohen IR (2010) An antibody profile of systemic lupus erythematosus detected by antigen microarray. Immunology 130(3):337-343. doi:10.1111/j.1365-2567. 2010.03245.x 